\title{
Localisation of aluminium by histochemical and electron probe $x$-ray microanalytical techniques in bone tissue of cases of renal osteodystrophy
}

\author{
PS SMITH, J McCLURE \\ From the Adelaide Bone and Joint Research Unit and the Division of Tissue Pathology, Institute of Medical and \\ Veterinary Science, Frome Road, Adelaide, South Australia
}

SUMMARY Histochemical studies and electron probe $x$-ray microanalysis for aluminium have been performed on 16 samples of undecalcified bone from cases of renal osteodystrophy associated with a syndrome suggestive of dialysis encephalopathy (five cases), age and sex matched controls for these and a group of patients with chronic renal failure (six cases) who have never been on haemodialysis. Aluminium was detected only in the patients with a dialysis encephalopathy-like syndrome. This group had significant histological bone disease the features of which were broadly consistent with the so-called atypical renal osteomalacia which is thought to be due to a metal toxin. Aluminium was demonstrated at the interface between osteoid and mineralised tissue-that is, at the site of the calcification front, where it could interfere with the mineralisation process. In the group of patients who had never been subjected to haemodialysis there was also significant histological bone disease but no evidence of aluminium accumulation. In this group the bone disease was of a more typical pattern of osteomalacic changes coupled with those of hyperparathyroidism.

Berlyne et $a l^{1}$ reported that hyperaluminaemia occurred in patients with advanced renal failure and suggested that the sources of aluminium were the dialysis fluid and orally consumed aluminium containing ion exchange resins and aluminium hydroxide used therapeutically to control hyperkalaemia and hyperphosphataemia respectively. More recently Kaehny $e a^{2}$ have demonstrated significant transfers of aluminium from dialysate to patient during haemodialysis. The importance of aluminium transfer to and accumulation in patients on haemodialysis is illustrated by the work of Alfrey et al ${ }^{3}$ who suggest that aluminium intoxication is responsible for the dialysis encephalopathy syndrome.

It has also been demonstrated by Parsons et al $^{4}$ that bone samples from patients treated with intermittent haemodialysis have high aluminium concentrations. Platts $e t \mathbf{a l}^{\mathbf{5}}$ found that patients undergoing home dialysis in the Trent region who developed dialysis encephalopathy and suffered spontaneous fractures were being dialysed against water which had a higher concentration of aluminium than those

Accepted for publication 16 March 1982 who did not develop these complications.

Ward $e a^{6}{ }^{6}$ found that osteomalacia was present in $15 \%$ of patients dialysed against deionised water and in $70 \%$ of patients dialysed against softened water from the same original source in the Newcastleupon-Tyne area. The aluminium content of this source was high. Serum aluminium concentrations were higher in patients using softened water than those using deionised water and it was found that deionisation diminished the water aluminium content to a greater extent than the softening process. A later survey by the Newcastle group of 1293 patients being treated in 18 dialysis centres in Great Britain revealed a highly significant rank correlation of the incidence of both fracturing osteomalacic dialysis osteodystrophy and dialysis encephalopathy with the aluminium content of the water used to prepare the dialysate. $^{7}$

All this adds up to a substantial body of evidence suggesting a link between aluminium accumulation and the development of dialysis osteodystrophy. Yet the nature of this evidence is still circumstantial and there is no proven causal relation between the development of osteomalacia and increased concentrations of aluminium in blood or bone. Thus Ellis $e t$ 
$a l^{8}$ found no significant relation between the presence or severity of osteomalacia and the bone aluminium content of 34 patients with chronic renal failure. These workers were unable to demonstrate the precise localisation of aluminium in undecalcified bone blocks either by Stereoscan scanning electron microscopy or by histochemical means and they attributed this failure to the low concentrations of aluminium involved.

It is of course of prime importance to determine the localisation of accumulated aluminium in the bones of renal failure patients on haemodialysis to see if it is capable of exerting an inhibitory effect on the mineralisation process. Towards this end undecalcified bone tissue from a total of 16 patients was studied by a number of available histochemical techniques and by electron probe $x$-ray microanalysis to determine the presence or absence of aluminium and its localisation if present.

\section{Material and methods}

The studied specimens were derived from three groups of patients. The first group (of five individuals) consisted of patients in chronic renal failure who had been treated by haemodialysis and who had developed a syndrome suggestive of dialysis encephalopathy. The second group (again of five individuals) consisted of age and sex matched controls. These were patients in whom bone biopsies had been performed and in whom there was no evidence of renal failure by clinical and biochemical assessment. The third group (of six individuals) also had renal failure and had never been treated by haemodialysis. Members of this group were not age or sex matched against the first group. Clinical data on these patients are given in Tables 1,2 , and 3.

In each instance cores of bone were taken from the left anterior iliac crest from just behind the

Table 1 Clinical and biochemical details of patients in group 1 who had chronic renal failure on haemodialysis and in whom there was evidence of dialysis encephalopathy

\begin{tabular}{|c|c|c|c|c|c|c|}
\hline Case & $\begin{array}{l}\text { Age } \\
(y r)\end{array}$ & Sex & Cause of renal failure & $\begin{array}{l}\text { Duration of } \\
\text { haemodialysis }\end{array}$ & Renal status at time of bone biopsy & Evidence of encephalopathy \\
\hline 1 & 63 & $F$ & $\begin{array}{l}\text { Chronic } \\
\text { glomerulonephritis. } \\
\text { Anti-GBM antibodies }\end{array}$ & 42 months & $\begin{array}{l}\text { Creatinine } 0.92 \mathrm{mmol} / \mathrm{l}(\mathrm{NR} 0 \cdot 05 \rightarrow 0 \cdot 12) \\
\text { Urea } 31.8 \mathrm{mmol} / \mathrm{N}(\mathrm{NR} 3 \cdot 0 \rightarrow 8 \cdot 0) \\
\text { Calcium } 2 \cdot 70 \mathrm{mmol} / \mathrm{N}(\mathrm{NR} 2 \cdot 2 \rightarrow 2 \cdot 55) \\
\text { Phosphate } 1.86 \mathrm{mmol} / \mathrm{l}(\mathrm{NR} 0 \cdot 70 \rightarrow 1 \cdot 25) \\
\text { Alkaline phosphatase } 78 \mathrm{U} / 1(\mathrm{NR} 30-110) \\
\text { Albumin } 37 \mathrm{~g} / \mathrm{l}(\mathrm{NR} 34 \rightarrow 45)\end{array}$ & $\begin{array}{l}\text { Hallucinations, decreased } \\
\text { consciousness, CT scan } \\
\text { suggested cerebral atrophy. }\end{array}$ \\
\hline 2 & 59 & $\mathbf{M}$ & $\begin{array}{l}\text { Congenital absence of } \\
\text { right kidney. } \\
\text { Polycystic left kidney }\end{array}$ & 24 months & $\begin{array}{l}\text { Creatinine } 1.03 \mathrm{mmol} / \mathrm{l}(\mathrm{NR} 0 \cdot 05 \rightarrow 0 \cdot 12) \\
\text { Urea } 26 \cdot 8 \mathrm{mmol} / \mathrm{N}(\mathrm{NR} 3 \cdot 0 \rightarrow 8.0) \\
\text { Calcium } 2 \cdot 48 \mathrm{mmol} / \mathrm{NR} \cdot 2 \cdot 2 \rightarrow 2 \cdot 55) \\
\text { Phosphate } 1.31 \mathrm{mmol} / \mathrm{NR}(\mathrm{NR} \cdot 70 \rightarrow 1 \cdot 25) \\
\text { Alkaline phosphatase } 50 \mathrm{U} / \mathrm{l}(\mathrm{NR} 30-110) \\
\text { Albumin } 40 \mathrm{~g} / \mathrm{NR} 34 \rightarrow 45)\end{array}$ & $\begin{array}{l}\text { "Shakes" after } \\
\text { haemodialysis accompanied } \\
\text { by slurring of speech and } \\
\text { short term memory loss. } \\
\text { Marked intention tremor. }\end{array}$ \\
\hline 3 & 55 & $\mathbf{F}$ & $\begin{array}{l}\text { Analgesic } \\
\text { nephropathy }\end{array}$ & 20 months & $\begin{array}{l}\text { Creatinine } 1.04 \mathrm{mmol} / \mathrm{N}(\mathrm{NR} 0 \cdot 05 \rightarrow 0 \cdot 12) \\
\text { Urea } 45 \cdot 2 \mathrm{mmol} / \mathrm{I}(\mathrm{NR} 3 \cdot 0 \rightarrow 8 \cdot 0) \\
\text { Calcium } 2 \cdot 38 \mathrm{mmol} / \mathrm{l}(\mathrm{NR} 2 \cdot 20 \rightarrow 2 \cdot 55) \\
\text { Phosphate } 2 \cdot 48 \mathrm{mmol} / \mathrm{l}(\mathrm{NR} 0 \cdot 70 \rightarrow 1 \cdot 25) \\
\text { Alkaline phosphatase } 166 \mathrm{U} / \mathrm{l}(\mathrm{NR} 30-110) \\
\text { Albumin } 39 \mathrm{~g} / \mathrm{I}(\mathrm{NR} 34 \rightarrow 45)\end{array}$ & $\begin{array}{l}\text { Shaking of hands and } \\
\text { aphasia during } \\
\text { haemodialysis. EEG } \\
\text { showed slow } \alpha \text { wave } \\
\text { activity. Grand mal fits. }\end{array}$ \\
\hline 4 & 52 & $\mathbf{F}$ & Reflux nephropathy & 41 months & $\begin{array}{l}\text { Creatinine } 1.02 \mathrm{mmol} / \mathrm{N}(\mathrm{NR} 0 \cdot 05 \rightarrow 0 \cdot 12) \\
\text { Urea } 33 \cdot 3 \mathrm{mmol} / \mathrm{N}(\mathrm{NR} 3 \cdot 0 \rightarrow 8 \cdot 0) \\
\text { Calcium } 2 \cdot 78 \mathrm{mmol} / \mathrm{l}(\mathrm{NR} 2 \cdot 20 \rightarrow 2 \cdot 55) \\
\text { Phosphate } 1.32 \mathrm{mmol} / \mathrm{l}(\mathrm{NR} 0 \cdot 70 \rightarrow 1 \cdot 25) \\
\text { Alkaline phosphatase } 161 \mathrm{U} / \mathrm{l}(\mathrm{NR} 30-110) \\
\text { Albumin } 43 \mathrm{~g} / \mathrm{l}(\mathrm{NR} 34 \rightarrow 45)\end{array}$ & $\begin{array}{l}\text { Grand mal epileptiform fits. } \\
\text { EEG showed "generalised } \\
\text { abnormality". Unable to } \\
\text { follow complex commands. } \\
\text { Expressive dysphasia after } \\
\text { haemodialysis. Memory } \\
\text { impairment. History of } \\
\text { manic depressive psychosis. }\end{array}$ \\
\hline 5 & 48 & $\mathbf{M}$ & $\begin{array}{l}\text { Chronic } \\
\text { glomerulonephritis } \\
\text { and malignant } \\
\text { hypertension }\end{array}$ & 48 months & $\begin{array}{l}\text { Creatinine } 0.74 \mathrm{mmol} / \mathrm{N}(\mathrm{NR} 0 \cdot 05 \rightarrow 0 \cdot 12) \\
\text { Urea } 22 \cdot 6 \mathrm{mmol} / \mathrm{I}(\mathrm{NR} 3 \cdot 0 \rightarrow 8 \cdot 0) \\
\text { Calcium } 2.4 \mathrm{mmol} / \mathrm{N}(\mathrm{NR} 2 \cdot 20 \rightarrow 2 \cdot 55) \\
\text { Phosphate } 1.97 \mathrm{mmol} / \mathrm{l}(\mathrm{NR} 0 \cdot 70 \rightarrow 1 \cdot 25) \\
\text { Alkaline phosphatase } 205 \mathrm{U} / 1(\mathrm{NR} 30-110) \\
\text { Albumin } 36 \mathrm{~g} / \mathrm{N}(\mathrm{NR} 34 \rightarrow 45)\end{array}$ & $\begin{array}{l}\text { Grand mal epileptiform fits. } \\
\text { EEG showed generalised } \\
\text { abnormality which was } \\
\text { more marked after } \\
\text { haemodialysis. Slurring of } \\
\text { speech, memory } \\
\text { impairment and myoclonus. } \\
\text { History of manic depressive } \\
\text { psychosis. }\end{array}$ \\
\hline
\end{tabular}


Table 2 Clinical and biochemical details of the age and sex matched controls for group 1

\begin{tabular}{|c|c|c|c|c|}
\hline Case & $\begin{array}{c}\text { Age } \\
(y r)\end{array}$ & $\operatorname{Sex}$ & Clinical history & Assessment of renal function \\
\hline 1 & 63 & $\mathbf{F}$ & $\begin{array}{l}\text { Six months previously she had a fall and sustained a } \\
\text { crush fracture of T11, T12. Investigated for } \\
\text { osteoporosis. } \\
\text { PMH: nil of significance. }\end{array}$ & 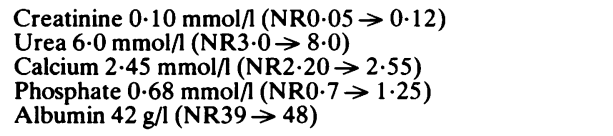 \\
\hline 2 & 59 & $\mathbf{M}$ & $\begin{array}{l}\text { Investigated for episodic mild hypercalcaemia. } \\
\text { Thyroid function normal. Serum parathormone level } \\
\text { normal. } \\
\text { PMH: three proven myocardial infarcts. }\end{array}$ & $\begin{array}{l}\text { Creatinine } 0.09 \mathrm{mmol} / /(\mathrm{NR} 0 \cdot 05 \rightarrow 0 \cdot 12) \\
\text { Urea } 4.70 \mathrm{mmol} / \mathrm{N}(\mathrm{NR} 3 \cdot 0 \rightarrow 8 \cdot 0) \\
\text { Calcium } 2 \cdot 33 \mathrm{mmol} / \mathrm{NR2} \cdot 20 \rightarrow 2 \cdot 55) \\
\text { Phosphate } 0.86 \mathrm{mmol} / \mathrm{NR}(\mathrm{NR} 0.7 \rightarrow 1 \cdot 25) \\
\text { Albumin } 41 \mathrm{~g} / \mathrm{l}(\mathrm{NR} 39 \rightarrow 48) \\
\text { Creatinine clearance } 101 \mathrm{ml} / \mathrm{min}(\mathrm{NR} 90 \rightarrow 180) \\
24-\text { hour urine volume } 2150 \mathrm{ml} \\
\text { Urinary creatinine } 13.1 \mathrm{mmol} / 24 \mathrm{~h}(\mathrm{NR} 8 \cdot 8 \rightarrow 23 \cdot 0)\end{array}$ \\
\hline 3 & 55 & $\mathbf{F}$ & $\begin{array}{l}\text { Fractured two right metacarpals after a fall. } \\
\text { Investigated for osteoporosis. } \\
\text { PMH: nil of significance. }\end{array}$ & $\begin{array}{l}\text { Creatinine } 0.07 \mathrm{mmol} / \mathrm{l}(\mathrm{NR} 0 \cdot 05 \rightarrow 0 \cdot 12) \\
\text { Urea } 5.1 \mathrm{mmol} / \mathrm{l}(\mathrm{NR} 3 \cdot 0 \rightarrow 8 \cdot 0) \\
\text { Calcium } 2 \cdot 3 \mathrm{mmol} / \mathrm{l}(\mathrm{NR} 2 \cdot 20 \rightarrow 2 \cdot 55) \\
\text { Phosphate } 1.02 \mathrm{mmol} / \mathrm{N}(\mathrm{NR} 0 \cdot 7 \rightarrow 1 \cdot 25) \\
\text { Albumin } 40 \mathrm{~g} / \mathrm{l}(\mathrm{NR} 39 \rightarrow 48)\end{array}$ \\
\hline 4 & 52 & $\mathbf{F}$ & $\begin{array}{l}\text { Right colles fracture after a fall. Investigated for } \\
\text { osteoporosis. } \\
\text { PMH: nil of significance. }\end{array}$ & $\begin{array}{l}\text { Creatinine } 0.06 \mathrm{mmol} / \mathrm{l}(\mathrm{NR} 0.05 \rightarrow 0.12) \\
\text { Urea } 6.0 \mathrm{mmol} / \mathrm{N}(\mathrm{NR} 3.0 \rightarrow 8.0) \\
\text { Calcium } 2.40 \mathrm{mmol} / \mathrm{N}(\mathrm{NR} 2 \cdot 20 \rightarrow 2.55) \\
\text { Phosphate } 0.72 \mathrm{mmol} / \mathrm{NR}(\mathrm{NR} 0.7 \rightarrow 1.25) \\
\text { Albumin } 43 \mathrm{~g} / \mathrm{l}(\mathrm{NR} 39 \rightarrow 48)\end{array}$ \\
\hline 5 & 48 & $\mathbf{M}$ & $\begin{array}{l}\text { Reformed alcoholic who fell and sustained a crush } \\
\text { fracture of T12. Investigated for metabolic bone } \\
\text { disease. }\end{array}$ & 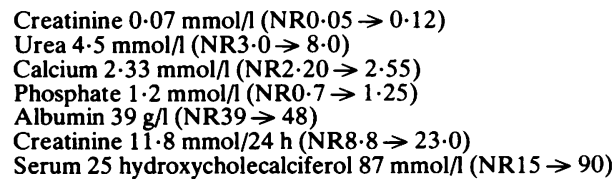 \\
\hline
\end{tabular}

anterior superior spine and through the top of the crest passing down between outer and inner cortices. The specimens were processed and embedded in araldite. Thin $(7 \mu \mathrm{m})$ sections were cut on a Jung $\mathrm{K}$ microtome without prior decalcification. Multiple sections were cut and stained by the von Kossa method with various counterstains including haematoxylin and eosin and the van Gieson method. Calcification fronts were stained with toluidine blue and with haematoxylin as suggested by Raina. ${ }^{\circ}$ In three cases (in group 3) tetracycline had been administered in vivo and the calcification fronts were determined by ultraviolet light fluorescence. There was a high degree of correlation between the results of this technique and staining with either toluidine blue or haematoxylin.

Quantitative assessments of several parameters were made in each case. These assessments were restricted to cancellous bone. The total cancellous bone volume, the osteoid volume and the percentage of the total bone which was mineralised were estimated from multiple sections (treated by the von Kossa technique and the van Gieson counterstain) using the Quantimet image analysis computer. The percentage of the trabecular surface covered by osteoid was estimated by a line-intersect technique using an eyepiece graticule. Calcification fronts were determined by a similar technique and expressed as the percentage of osteoid seams bearing a calcification front. An assessment of the thickness of the osteoid seams was made by inspecting the seams in polarised light and determining the maximum number of birefringent lamellae present. Total resorbing or crenated surfaces were expressed as the percentage of the total trabecular surfaces occupied by these surfaces. A distinction was also made between active resorbing surfaces and inactive resorbing surfaces in that the former were occupied by osteoclasts and the latter not occupied by these cells.

Sections from each case were stained by three separate histochemical methods which may be used to demonstrate the presence of aluminium salts. These methods were obtained from Pearse ${ }^{10}$ and were (i) the ammonium aurintricarboxylate (aluminon) method (ii) the solochrome azurine method (with and without alkali pretreatment) and (iii) the acid solochrome cyanine method. The latter two methods were used to stain one section from each case.

After sections had been obtained for histological and histochemical studies the surface of each Araldite block was polished to within $1 \mu \mathrm{m}$ using diamond 
paste, coated with carbon and analysed with a Jeol 733 Superprobe scanning electron microanalyser. This instrument had both energy dispersive and wavelength dispersive $x$-ray analytical capabilities. Initially studies were performed using the Ortec EEDS-II energy dispersive $x$-ray analysis system but because of negative results obtained with this system the wavelength dispersive $x$-ray analysis system was eventually used to perform the complete analytical study.

This involved examining selected areas at a standard magnification and photographing the secondary electron images. These areas were analysed for calcium and aluminium $x$-ray emissions. Linear focusing

Table 3 Clinical and biochemical details of patients in group 3 who had never been treated by haemodialysis

\begin{tabular}{llll}
\hline Case & $\begin{array}{c}\text { Age } \\
(y r)\end{array}$ & Sex & Cause(s) of renal failure \\
\hline 1 & 53 & F & $\begin{array}{l}\text { Hypertension. Duration of renal failure approximately } \\
10 \mathrm{yr}\end{array}$
\end{tabular}

Renal function at the time of biopsy

Creatinine $0.70 \mathrm{mmol} / \mathrm{l}(\mathrm{NR} 0 \cdot 05 \rightarrow 0.12)$

Urea $32 \cdot 2 \mathrm{mmol} / \mathrm{l}(\mathrm{NR} 3 \cdot 0 \rightarrow 7 \cdot 6)$

Calcium $2 \cdot 53 \mathrm{mmol} / \mathrm{l}(\mathrm{NR} 2 \cdot 10 \rightarrow 2 \cdot 60)$

Phosphate $1.63 \mathrm{mmol} / \mathrm{l}(\mathrm{NR} 0.7 \rightarrow 1.30)$

Alkaline phosphatase $148 \mathrm{U} / \mathrm{N}(\mathrm{NR} 30 \rightarrow 110)$

Albumin $40 \mathrm{~g} / \mathrm{l}(\mathrm{NR} 35 \rightarrow 50)$

Nephrolithiasis. Gout. Hypertension. Duration of renal failure approximately $8 \mathrm{yr}$

Creatinine $0.37 \mathrm{mmol}(\mathrm{NR} 0 \cdot 05 \rightarrow 0 \cdot 12)$

Urea $16.3 \mathrm{mmol} / \mathrm{l}(\mathrm{NR} 3.0 \rightarrow 7.6)$

Calcium $1.18 \mathrm{mmol} / \mathrm{l}(\mathrm{NR} 2 \cdot 10 \rightarrow 2 \cdot 60)$

Phosphate $1.38 \mathrm{mmol} / \mathrm{l}(\mathrm{NR} 0.7 \rightarrow 1.30)$

Alkaline phosphatase $333 \mathrm{U} / \mathrm{l}(\mathrm{NR} 30 \rightarrow 110)$

Albumin $37 \mathrm{~g} / \mathrm{l}(\mathrm{NR} 35 \rightarrow 50)$

Polycystic kidneys. Duration of renal failure approximately $10 \mathrm{yr}$

Creatinine $1.40 \mathrm{mmol} / \mathrm{l}(\mathrm{NR} 0 \cdot 05 \rightarrow 0 \cdot 12)$

Urea $54.9 \mathrm{mmol} / \mathrm{l}(\mathrm{NR} 3.0 \rightarrow 7.6)$

Calcium $2 \cdot 36 \mathrm{mmol} / \mathrm{l}(\mathrm{NR} 2 \cdot 10 \rightarrow 2 \cdot 60)$

Phosphate $1.79 \mathrm{mmol} / \mathrm{l}(\mathrm{NR} 0.7 \rightarrow 1.30)$

Alkaline phosphatase $60 \mathrm{U} / \mathrm{l}(\mathrm{NR} 30 \rightarrow 110)$

Albumin $40 \mathrm{~g} / \mathrm{l}(\mathrm{NR} 35 \rightarrow 50)$

Reflux nephropathy, fashioning of ileal loop, recurrent urinary tract infections. Duration of renal failure approximately $15 \mathrm{yr}$

Creatinine $0.72 \mathrm{mmol} / \mathrm{l}(\mathrm{NR} 0.05 \rightarrow 0.12)$

Urea $51.7 \mathrm{mmol} / \mathrm{l}(\mathrm{NR} 3 \cdot 0 \rightarrow 7.6)$

Calcium $1.91 \mathrm{mmol} / \mathrm{l}(\mathrm{NR} 2 \cdot 10 \rightarrow 2 \cdot 60)$

Phosphate $1.38 \mathrm{mmol} / \mathrm{l}(\mathrm{NR} 0.7 \rightarrow 1.30)$

Alkaline phosphatase $417 \mathrm{U} / 1(\mathrm{NR} 30 \rightarrow 110)$

Albumin $37 \mathrm{~g} / \mathrm{l}(\mathrm{NR} 35 \rightarrow 50)$

$5 \quad 30 \quad$ F $\quad$ Reflux nephropathy, megaureters, scarred cotracted kidney, recurrent urinary tract infections. Duration approximately $30 \mathrm{yr}$

Creatinine $0.45 \mathrm{mmol} / \mathrm{l}(\mathrm{NR} 0.05 \rightarrow 0.12)$

Urea $34.6 \mathrm{mmol} / \mathrm{l}(\mathrm{NR} 3.0 \rightarrow 7.6)$

Calcium $2.56 \mathrm{mmol} / \mathrm{l}(\mathrm{NR} 2 \cdot 10 \rightarrow 2 \cdot 60)$

Phosphate $2.03 \mathrm{mmol} / \mathrm{l}(\mathrm{NR} 0 \cdot 7 \rightarrow 1 \cdot 30)$

Alkaline phosphatase $447 \mathrm{U} / \mathrm{l}(\mathrm{NR} 30 \rightarrow 110)$

Albumin $29 \mathrm{~g} / \mathrm{l}(\mathrm{NR} 35 \rightarrow 50)$

$6 \quad 53 \quad \mathrm{~F}$

Analgesic nephropathy. Duration of renal failure

Creatinine $0.66 \mathrm{mmol} / \mathrm{l}(\mathrm{NR} 0.05 \rightarrow 0.12)$

Urea $32.9 \mathrm{mmol} / \mathrm{l}(\mathrm{NR} 3.0 \rightarrow 7.6)$

Calcium $1.99 \mathrm{mmol} / \mathrm{l}(\mathrm{NR} 2 \cdot 10 \rightarrow 2.60)$

Phosphate $2.06 \mathrm{mmol}(\mathrm{NR} 0.7 \rightarrow 1.30$ )

Alkaline phosphatase $228 \mathrm{U} / \mathrm{l}(\mathrm{NR} 30 \rightarrow 110)$

Albumin $36 \mathrm{~g} / \mathrm{l}(\mathrm{NR} 35 \rightarrow 50)$

Table 4 Mean values and standard error of the mean (SEM) of histoquantitative parameters of each of the three study group

Using Student's t test a comparison has been made between the means of each group for each parameter. A signiferanc.

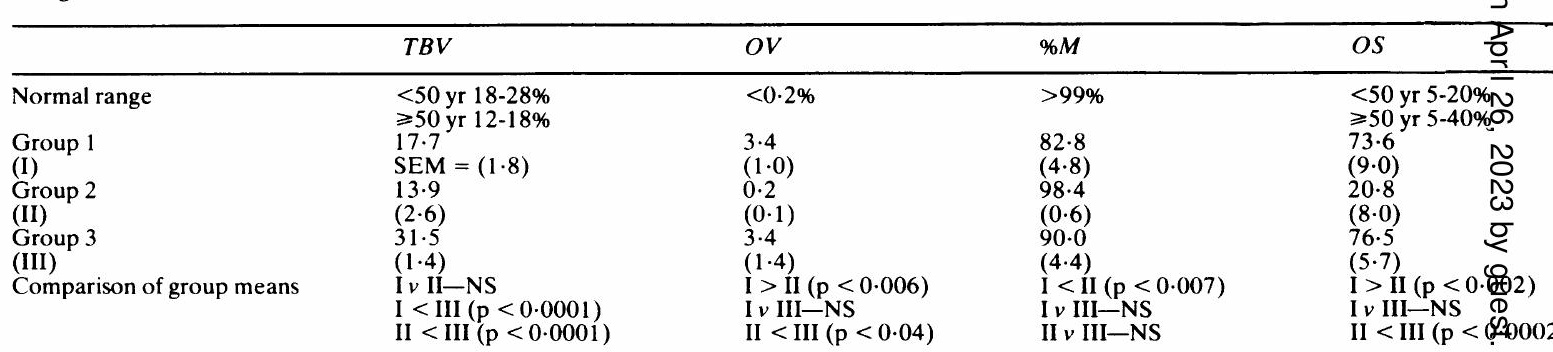

TBV = total bone volume $\mathrm{OV}=$ osteoid volume $\% \mathrm{M}=$ percentage mineralisation; $\mathrm{OS}=$ percentage of trabecular surface covered by osteoid; $\mathrm{CF}=$ percentage of ostegrd sea resorbing surface. 
Bragg crystal spectrometers with PET and TAP crystals were used for $x$-ray detection using calcium phosphate and aluminium oxide as standards. The high beam currents of $120 \mathrm{nA}$ at $15 \mathrm{kV}$ used to demonstrate aluminium in the tissues severely damaged the softer components (osteoid and marrow tissues) of the analysed area, but left the mineralised bone intact. Three areas from each patient were analysed in this way and identical beam currents were used for each analysis.

\section{Results}

The results of the histoquantitative assessments are detailed in Table 4. Both in group 1 (Fig. 1) and group 3 (Fig. 2) there was significant bone disease. In

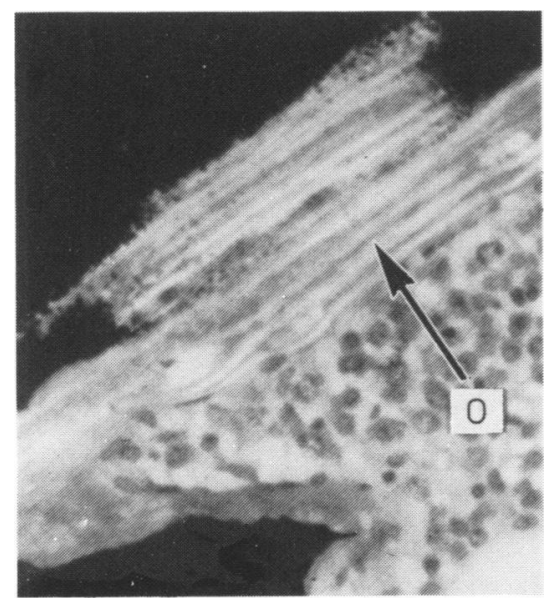

Fig. 1 Case 1, group 1. This undecalcified bone trabecular structure has a thickened osteoid seam $(O)$. This is observed in polarised light to demonstrate birefringent parallel lamellae. von Kossa and haematoxylin and eosin $\times 200$. both groups there was an increased osteoid volume, diminution in the degree of mineralisation, an increase in the extent of the trabecular surface covered by osteoid, increased osteoid seam thickness and a decrease in the extent of the calcification fronts. There were differences in the degree of change in these parameters. Although in two cases of group 1 there was increased resorptive activity, manifest as increased surface resorption and trabecular "tunnelling" (Fig. 3), the mean total resorbing surface extent for the group was not abnormally high. Resorptive activity was a much more prominent feature of group 3 . In the only case in which the total resorbing surface was not raised the active resorbing

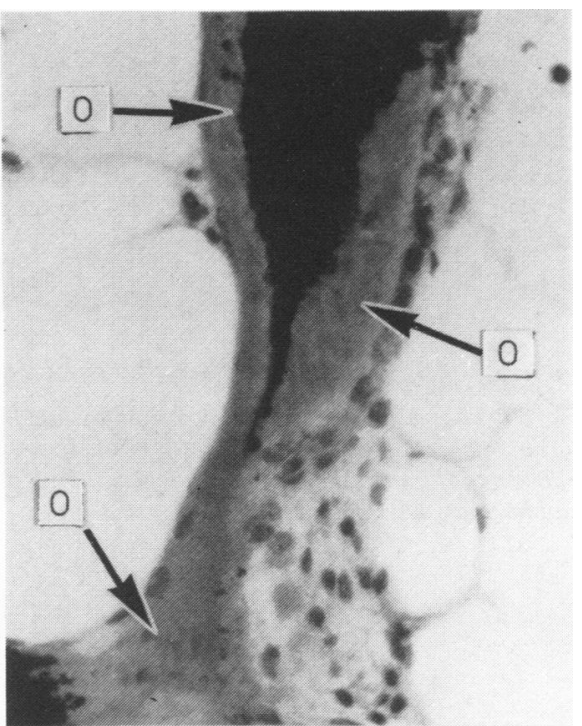

Fig. 2 Undecalcified bone section from case 2, group 3. Thickened, extensive osteoid seams $(O)$ cover the black mineralised tissue. von Kossa and haematoxylin and eosin $\times 200$.

2ormal range is that used for the population of the Adelaide area. evel of $p<0.05$ is used and the results are included in the Table (NS = not significant)

\begin{tabular}{|c|c|c|c|c|}
\hline$' F$ & $M O L$ & $A R$ & $I R$ & $T R$ \\
\hline $.70 \%$ & $<4$ & $<1 \cdot 5 \%$ & $<15 \%$ & $<16.5 \%$ \\
\hline $\begin{array}{l}0 \cdot 5 \\
7 \cdot 0) \\
2 \cdot 3 \\
j \cdot 8) \\
1.9 \\
3 \cdot 6) \\
<\text { II }(\mathrm{p}<0.0003) \\
v \text { III-NS } \\
\text { I }>\text { III }(\mathrm{p}<0.006)\end{array}$ & $\begin{array}{l}8 \\
(2.3) \\
1.6 \\
(0.2) \\
2.8 \\
(0.4) \\
\text { I }>\text { II }(\mathrm{p}<0.02) \\
\text { I }>\text { III }(\mathrm{p}<0.02) \\
\text { II }<\text { III }(\mathrm{p}<0.02)\end{array}$ & $\begin{array}{l}2 \cdot 4 \\
(1 \cdot 1) \\
0 \cdot 5 \\
(0 \cdot 5) \\
3 \cdot 4 \\
(0 \cdot 8) \\
\text { I }>\text { II }(\mathrm{p}<0.05) \\
\text { I } v \text { III-NS } \\
\text { II }<\text { III }(\mathrm{p}<0.01)\end{array}$ & $\begin{array}{l}12 \cdot 0 \\
(1 \cdot 7) \\
9 \cdot 4 \\
(3 \cdot 8) \\
14 \cdot 9 \\
(3 \cdot 3) \\
\text { I } v \text { II-NS } \\
\text { I } v \text { II-NS } \\
\text { II } v \text { III-NS }\end{array}$ & $\begin{array}{l}14 \cdot 4 \\
(2 \cdot 7) \\
9 \cdot 9 \\
(4 \cdot 0) \\
18 \cdot 3 \\
(3 \cdot 7) \\
\text { I } v \text { II-NS } \\
\text { I } v \text { III-NS } \\
\text { II } v \text { III-NS }\end{array}$ \\
\hline
\end{tabular}

earing a calcification front; $M O L=$ maximum number of birefringent lamellae in osteoid seams; $A R=$ active resorbing surface; $I R=$ inactive resorbing surface; TR = total 


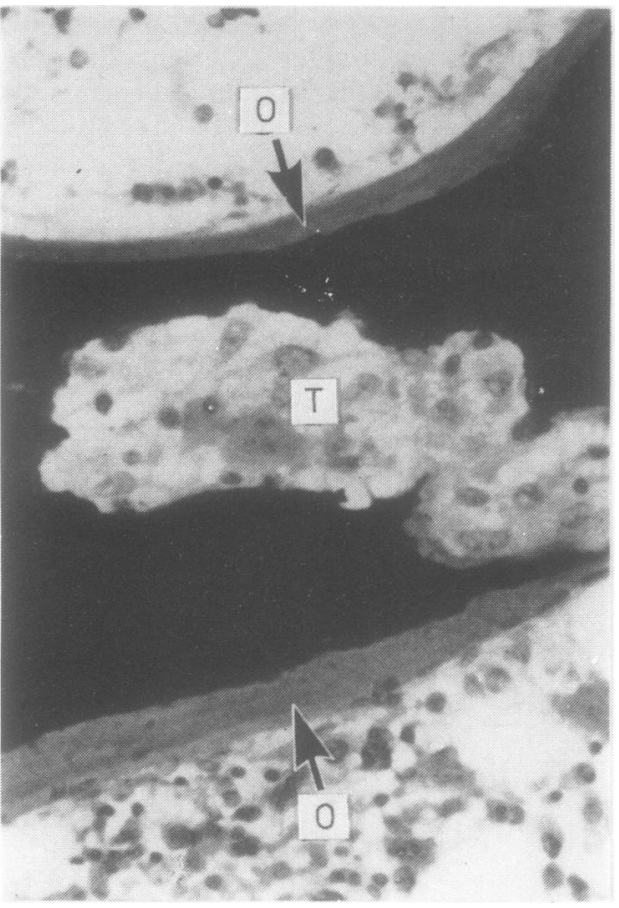

Fig. 3 The trabecular surface is covered by osteoid $(O)$ in this section from case 1 , group 1 . There is trabecular "tunnelling" (T) by osteoclasts. von Kossa and haematoxylin and eosin $\times 200$.

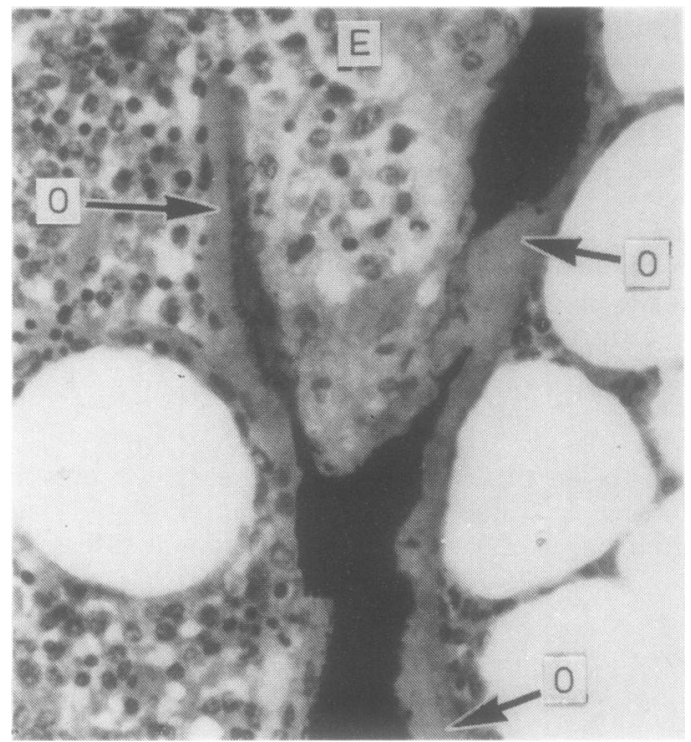

Fig. 4 In this sample from case 2, group 3 there is excess osteoid $(O)$. There is a deep excavation $(E)$ of the trabecular substance by osteoclasts. von Kossa and haematoxylin and eosin $\times 200$.

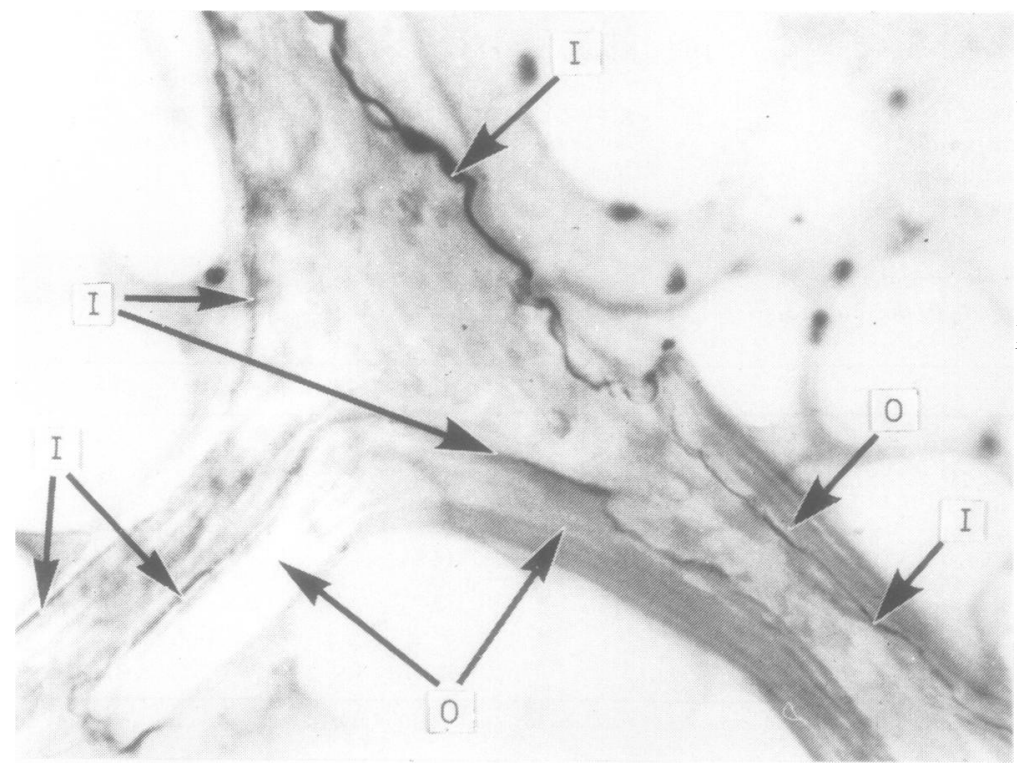

Fig. 5 Undecalcified section from case 1 , group 1 examined in polarised light. The osteoid seams are marked $O$ and the lines of positive aluminon reaction are marked I. Aluminon $\times 200$. 


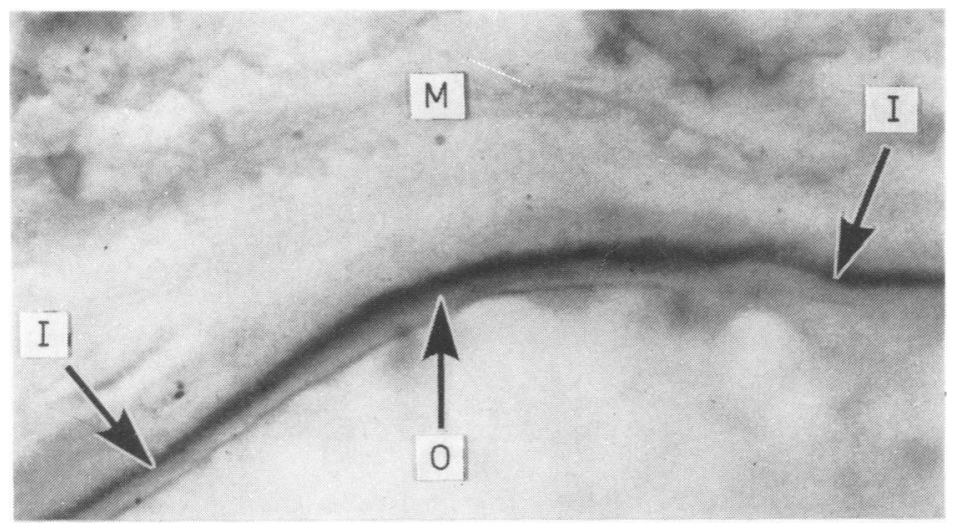

Fig. 6 The margin of a trabecular structure is shown. There is a thin osteoid seam $(O)$ and a linear positive aluminon reaction (I). Mineralised tissue is marked $M$ (case 1 , group 1). Aluminon $\times 400$.

surface value was at the limit of normality and histologically trabecular excavations were observed (Fig. 4).

Positive histochemical staining reactions were observed with the three techniques listed above in all sections studied from the cases in group 1 (Figs. 5 and 6). The ammonium aurintricarboxylate method was found to be the most useful and numerous sections were stained by this technique which has now been adopted as a routine test. Negative staining reactions were obtained with the three techniques in all sections studied from the cases of groups 2 and 3 .

Positive reactions were manifest as a linear colouration at the junction of osteoid and mineralised tissue-that is, in the region of the calcification front. These reactions were very extensive in all five cases and were present at the osteoid/ mineralised tissue junctions of thick and thin osteoid seams. Positive reactions were not obtained at the surface of the osteoid seams (marrow/osteoid junctions) or in the mineralised tissue. Examination of the sections in polarised light rendered the osteoid birefringent and emphasised the linear positive aluminon reaction. Positive reactions were not confined to the cancellous bone being present in cortical bone at the osteoid/mineralised tissue interface around Haversian canals.

The secondary electron images (Figs. 7a and 8a) clearly distinguish mineralised tissue, osteoid and marrow tissue and the junctional zones of these components. Mineralised tissue had a homogeneous light grey appearance and the osteoid was a darker grey usually with an array of parallel lamellae. The distribution of calcium determined by $x$-ray analysis at the same magnification precisely matched the mineralised bone area thus confirming the reality of the latter and by implication the reality of the osteoid (Figs. $7 \mathrm{~b}$ and $8 \mathrm{~b}$ ). The aluminium $x$-ray distributions were such that in group 1 cases there was an accumulation of this element at the osteoid/mineralised tissue junction and these distributions were therefore disposed in a linear fashion (Figs. 7c and 8c). Linear $x$-ray distributions for aluminium were not found in any of the areas studied in any of the cases in groups 2 and 3.

In group 1 cases a very faint aluminium $x$-ray distribution was seen in both mineralised bone and the marrow tissue, the concentration appearing to be higher in the former.

\section{Discussion}

The histochemical reaction used to demonstrate aluminium in the majority of the tissue sections studied was the aluminon method which was originally devised by Irwin. ${ }^{11}$ Aluminon is a dye (ammonium aurintricarboxylate) which forms a lake with a number of metallic ions under appropriate conditions. The lake is a complex precipitate formed by the dye molecule reacting with the particular metallic ion. The formation of lakes by aluminon with the hydroxides or basic acetates of aluminium, beryllium, iron, thorium and the rare earths has been reported by Middleton. ${ }^{12}$ Most of these lakes, with the exception of those formed by aluminium and beryllium are dissolved or decolorised by a solution containing ammonium ion buffered at a $\mathrm{pH}$ of $7 \cdot 2$. The beryllium lake is unstable in the absence of excess dye. Under the conditions of the Irwin technique the lake formed, which has a cherry-red/purple colour, is considered specific for the demonstration 

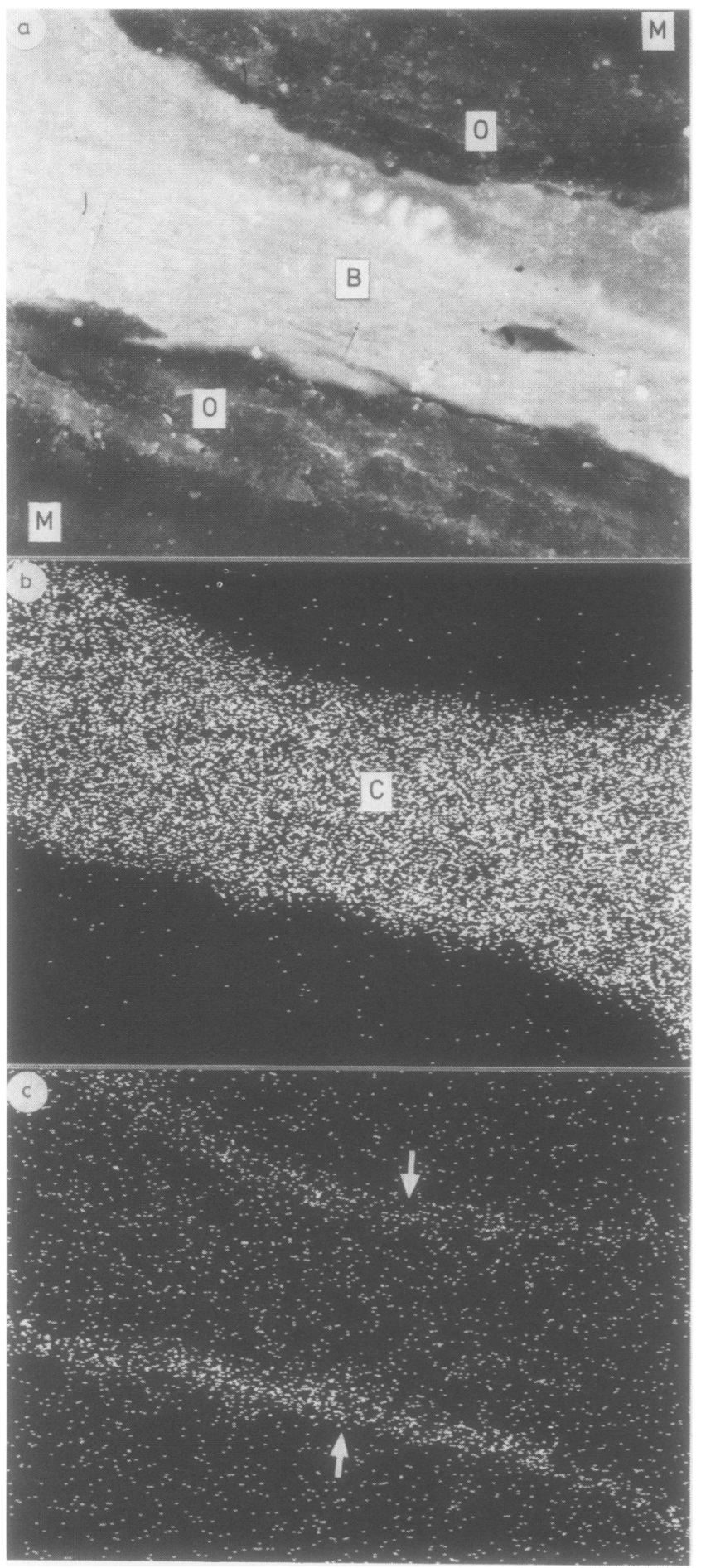

Fig. 7 Electron probe analysis of case 2, group 1 . (a) secondary electron image demonstrating marrow tissue $(M)$, wide osteoid seams $(O)$ and mineralised tissue $(B) \times 1200$. (b) $x$-ray distribution of calcium $(C)$ in the same area. This distribution corresponds exactly to the mineralise tissue $\times 1200$. (c) $x$-ray distribution of aluminium indicating the high abundances along the osteoid/mineralised tissue junction (arrows) $\times 1200$. 

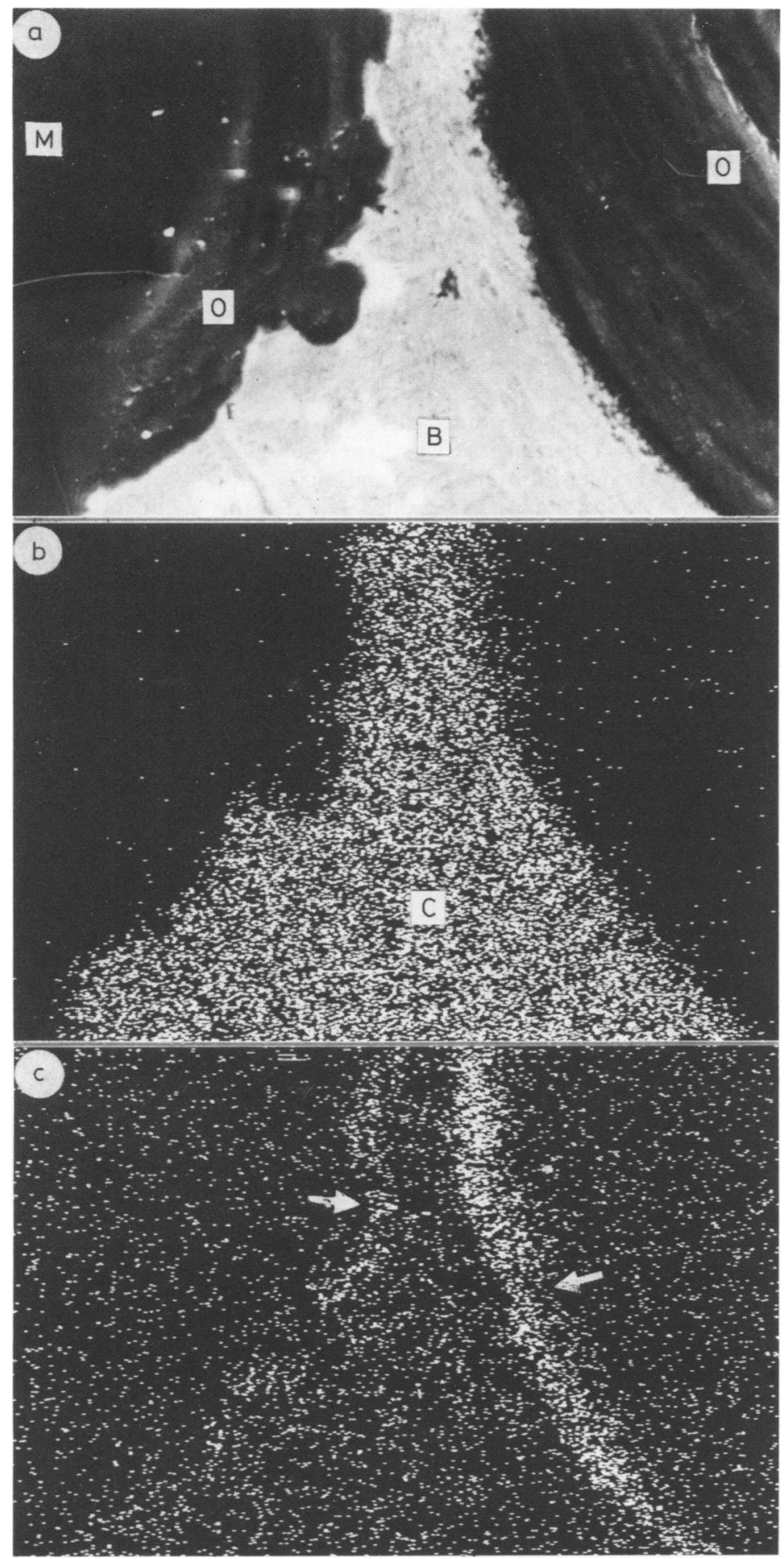

Fig. 8 Electron probe analysis of case 3, group 1. (a) secondary electron image demonstrating marrow tissue $(M)$, wide osteoid seams $(O)$ and mineralised tissue (B) $\times 1200$. (b) $x$-ray distribution of calcium $(C)$ in this area $\times 1200$. (c) $x$-ray distribution of aluminium again indicating high abundances along the osteoid/mineralised tissue junction (arrows) $\times 1200$ 
of the presence of aluminium.

This specificity was tested by the use of electron probe $x$-ray microanalysis. Initially studies were performed with the Ortec EEDS-II energy dispersive system but aluminium could not be demonstrated in histochemically positive cases. Bearing in mind that Ellis et $\mathbf{l}^{\mathbf{8}}$ were unable to demonstrate aluminium by Stereoscan scanning electron microscopy it was concluded that the energy dispersive system lacked the required sensitivity to demonstrate aluminium since this was probably present in low concentration. Assays for aluminium have not been performed on our material but in the cases studied by Ellis $e a^{8}$ the concentration in haemodialysed patients was of the order of 150 parts per million. It was therefore decided to use the more sensitive wavelength dispersive system and by using high beam currents positive results were obtained and satisfactory photographs obtained by using prolonged exposure times.

Both histochemical and electron probe techniques demonstrated the localisation of aluminium at the junction of osteoid and mineralised tissue-that is, at the site of the calcification fronts. In the $x$-ray analytical images very faint dispositions were also noted in mineralised tissue and marrow (the latter less than the former). These are regarded as background emissions although the slightly higher emissions noted in the mineralised tissues might indicate the presence of aluminium in very low concentrations not detectable by the Irwin technique. However, it must be emphasised that the vast bulk of the $x$-ray emissions were at the osteoid/mineralised tissue interface thereby confirming the selectivity of the Irwin technique and suggesting a very high degree of sensitivity.

The patients in group 1 were chosen for study because they had a clinical syndrome suggestive of dialysis encephalopathy. The evidence for this is presented in Table 1. The diagnosis might be considered doubtful in patients 4 and 5 in view of the psychiatric history in these two cases. It will be seen from Table 4 that in group 1 there was significant bone disease characterised by hyperosteoidosis and reduced calcification fronts. Group 2 represent age and sex matched controls for group 1. In this group are patients who had been investigated for suspected metabolic bone disease. There was no evidence of osteomalacia and clinical and biochemical studies specifically excluded renal dysfunction in these cases. These patients were used as controls in preference to available necropsy material because their renal function status at the time of bone biopsy was accurately known (Table 2). In addition an identical volume of tissue was taken from the same skeleta! site and processed in an identical way in both groups (this also applies to group 3 biopsies).
It was decided to examine the tissues of patients included in group 3 because these patients (although suffering from chronic renal failure) had never been treated by haemodialysis or any form of dialysis. The availability of biopsy material from such cases is extremely limited and it was not therefore possible to $\overline{ }$ match them precisely for age and sex with groups $1 \frac{\mathrm{m}}{\mathrm{m}}$ and 2. Their mean age of $41.6 \mathrm{yr}$ is less than that of $\mathbb{\nabla}$ groups 1 and $2(55.4 \mathrm{yr})$ and this due to the inclusion of a 15-year-old boy and a 30-year-old woman in the group. Their clinical data are presented in Table 3. It $\overrightarrow{0}$ is evident from Table 4 that these patients also had $\overrightarrow{\vec{\omega}}$ significant histological bone disease. Their mean $\stackrel{\omega}{\omega}$ osteoid volume was the same as that of group 1. This was a coincidence since the cases were not selected to obtain this parity. The histological pattern of the bone disease was hyperosteoidosis with diminished $\vec{\neg}$ calcification fronts and increased resorptive activity. $\vec{N}$ In contrast to groups 1 and 2 the mean total bone $\underset{\omega}{\infty}$ volume was higher in group 3 . Their calcification $\mathrm{O}$ fronts were also diminished but not to the same extent as group 1. A major difference was that $z$ resorptive activity was greater in group 3 than group 1.

Aluminium was demonstrated only in group $1 \frac{0}{0}$ cases and these patients had been treated by haemo- $\stackrel{\Phi}{-}$ dialysis (mean duration $=35$ months). The dialysa $\overrightarrow{0}$ used contained water derived from the Adelaie ? domestic water supply which, during the period of treatment of patients in group 1 , had an aluminiu解 content ranging from $1.23 \mathrm{mg} / \mathrm{l}$ to $1.00 \mathrm{mg} / \mathrm{l}$ (since that time active steps have been taken to reduce the aluminium content of the tap water and dialysate so $\mathbb{D}$ that the concentration in the latter is now 0.005 to $\stackrel{\Omega}{\Rightarrow}$ $0.01 \mathrm{mg} / \mathrm{l})$.

The fact that aluminium was not demonstrated in group 3 (five of whose patients had been taking oral aluminium hydroxide as a phosphate-binding agent) indicates that the aluminium burden of group 1 is dictated by haemodialysis using a dialysate with $a$ o high aluminium content. The localisation of aluminium at the calcification front could result in an 8 interference with the mineralisation process by mechanisms which at this stage must remain specula-응 tive but perhaps involving the preferential formation of aluminium phosphates. Aluminium was not demonstrated in the tissues of patients in group $3 \vec{N}$ who had never been treated by haemodialysis. These patients exhibited significant histological bone dis- $N$ ease and the absence of aluminium indicates that this element does not play a role in the causation of theiro renal osteodystrophy.

Cochran $^{13}$ has distinguished between typical (or classical) and atypical renal osteomalacia and sug- $\stackrel{\infty}{+}$ gests that the latter is a consequence of aluminium 0 toxicity. In typical renal osteomalacia plasma calcium 
is often low, phosphate concentration is normal or raised, alkaline phosphatase activity is raised, and histological features include osteosclerosis and hyperparathyroidism. The majority of the patients in group 3 fit well into this category.

In atypical renal osteomalacia, plasma calcium is often high, phosphate is normal or raised and alkaline phosphatase activity is normal. Spontaneous fractures occur and there is failure of response to vitamin $D$ or its active metabolites. Histologically there is no evidence of secondary hyperparathyroidism. There is a strong association with dialysis encephalopathy. In group 1 , cases 1 and 2 fit into this category on biochemical grounds. Histologically, however, there is increased resorption in case 1. Cases 3, 4, and 5 have raised alkaline phosphatase activities but not as marked as in group 3 and the histological findings are more consistent with atypical renal osteomalacia except that case 3 has increased resorptive activity. Case 1 was being treated with 1 , 25 hydroxyvitamin $D_{3}$ at the time of biopsy and about this time developed an avascular necrosis of the right head of femur. Cases 4 and 5 both sustained fractured necks of femur during an epileptiform fit and case 5 had rib fractures which resulted in rib cage deformities. Both of these cases had been treated with dihydrotachysterol.

Therefore, it seems that the cases in group 1 fit broadly into the category of atypical renal osteomalacia as defined by Cochran. ${ }^{13}$ Case 3 fits least well but this case exhibits the least severe histological bone disease and had been the least time on haemodialysis. Therefore this category of renal osteomalacia does indeed exhibit aluminium accumulation at a locus where the aluminium could interfere with the mineralisation process and produce the observed histological changes.

We wish to thank Mr W Mussard in the Lapidary Laboratory of the Department of Economic Geol- ogy, University of Adelaide for help with the preparation of the blocks for electron probe analysis. We wish to acknowledge the assistance of Mr B Griffin in the performance of the electron probe analysis at the Electron Optical Centre, University of Adelaide. We thank Mrs M Rowlands and Miss EA Goodwin for typing the manuscript.

\section{References}

1 Berlyne GM, Ben-Ari J, Pest D, et al. Hyperaluminaemia from aluminium resin in renal failure. Lancet 1970;ii:494-6.

${ }^{2}$ Kaehny WD, Alfrey AC, Holman RE, Shorrn WJ. Aluminium transfer during haemodialysis. Kidney Int 1977;12:361-5.

3 Alfrey AC, Le Gendre GR, Kaehny WD. The dialysis encephalopathy syndrome. Possible aluminium intoxication. $N$ Engl J Med 1976;294:184-8.

- Parsons V, Davies C, Goode C, Ogg C, Siddiqui J. Aluminium in bone from patients with renal failure. Br Med J 1971;iv:273-5.

${ }^{5}$ Platts MM, Goode GC, Hislop JS. Composition of domestic water supply and the incidence of fractures and encephalopathy in patients on home dialysis. Br Med J 1977;ii:657-60.

- Ward MD, Feest TG, Ellis HA, et al. Osteomalacic dialysis osteodystrophy: evidence of a water-borne aetiological agent, probably aluminium. Lancet 1978;i:841-4.

${ }^{7}$ Parkinson IS, Ward MK, Feest TG, Fawcett RWP, Kerr DNS. Fracturing dialysis osteodystrophy and dialysis encephalopathy. Lancet 1979; i:406-9.

- Ellis HA, McCarthy JH, Herrington J. Bone aluminium in haemodialysed patients and in rats injected with aluminium chloride: relationship to impaired bone mineralization. J Clin Pathol 1979;32:832-44.

- Raina V. Normal osteoid tissue. J Clin Pathol 1972;25:229-32.

${ }^{10}$ Pearse AGE. Histochemistry: theoretical and applied Edinburgh and London: Churchill Livingstone, 1972.

${ }^{11}$ Irwin DA. The demonstration of aluminium in animal tissues. Archives of Industrial Health 1955;12:218-20.

12 Middleton AR. Reaction of "Aluminon" with hydroxides of beryllium, rare earths, zirconium and thorium. J Am Chem Soc $1926 ; 48: 2125-6$.

${ }^{13}$ Cochran M. Aspects of renal bone disease. Aust NZ J Med 1981;11 (suppl 1):33-7.

Requests for reprints to: Dr J McClure, IMVS, Box 14, Rundle Street PO, Adelaide, South Australia 5000 